\title{
The Response of Accessibility Infrastructures for PWD to National Disability Policies in Higher Institutions of Developing Countries: Case Study of Ahmadu Bello University, Zaria and University of Malaya, Kuala Lumpur
}

\author{
Abubakar Ahmed ${ }^{1}$, Zakaria Al Cheikh Mahmoud Awad ${ }^{2}$ and Naziaty Mohd Yaacob ${ }^{3}$ \\ ${ }^{123}$ Department of Architecture, Faculty of Built Environment, University of Malaya, Kuala Lumpur, \\ Malaysia \\ 1ªhmed.abubakar0@gmail.com
}

\begin{abstract}
The paper adopted a case study approach to identify and compare the accessibility provisions to learning infrastructures and facilities of public higher-institutions for people (living) with disabilities (PWD) in developing countries, using Nigeria and Malaysia as case studies. One university from each country, Ahmadu Bello University (ABU), Zaria in Nigeria and University of Malaya (UM), Kuala Lumpur in Malaysia were selected. The objectives include identification of relevant buildings and accessibility provisions in them, using Audit checklist, comparison between the adequacies or otherwise of the facilities against the National policy provisions using content analysis. The study finds that UM have better provision of accessibility infrastructure but needs improvement. The expectation of the target audience is inclusive and Universal Design (UD) bottom-up approach and adherence to policy implementation. The study recommends adherence to the building regulations and standard requirement as informed by the respective national policy provisions to reduce accessibility restrictions in the two campuses.
\end{abstract}

Keywords: accessibility, developing-countries, higher-institutions, infrastructure, PWD

\section{INTRODUCTION}

Physical disability has for long determined social acceptability by considering certain body features as "normal" and any other as deformed and disabled. The body appearance informed the categorisation of the "disability" degree. Thus, an artificial paradigm of disability was created based on the so-called "normal" physical appearance of human body rather than human ability. According to Goldsmith (2007) life outside the paradigm of normal body is treated differently. The United Nation world report on disability acknowledged that the PWD are largest marginalized group and the slim history of the lives of PWD is not only a history of "silence of the poor" but a story of those the World Health Organisation (WHO) called "the poorest of the poor" (WHO, 2011).

The history of disability is a progressive development of several models based on the concept of physical outlook from charity model, medical, to the recent social model of disability. The charity model of disability presumes that people having apparent limitations should be looked at as the appropriate recipients of social and economic support by their immediate family and the community or government. Medical and scientific knowledge brought about changes in the life of the disabled people. Therefore "the medical model" concerned with removal of disease dominated the focus of attention in disability study. Disability continued to be seen as a life of medical and rehabilitative tragedy, which needs to be segregated in institutional confines. 
Micheline and Mason quoted in Holmes (1996) consider that that human body is "flexible and therefore "alterable" while society is "fixed and therefore unchangeable" this leaves the disabled with no choice but to adapt to the unfriendly environment that they might have found themselves in. Holmes however, has a different opinion. He sees that the reluctance of the society to employ measures to modify itself, rather than the impairment that causes the disability the most.

The recent "social model" shows a clearer understanding, that, the restrictions faced by PWD results (more) from social-cultural and economic barriers and are not part of the disability itself. Thus social model of disability emphasises that the society is the principal disabling force, marginalizing impaired people socially, economically and politically. Disability according to Social Model is all things that impose restrictions upon disabled people; especially in relation to the "oppressive" built environment (Bromley et al., 2007). In recent years, the social model has extended disability study into a multidimensional concept which embraces the human right elements such as the right to health care, education and social participation and protection.

The World Report on Disability estimated figure of more than 1 billion people living with disability today expects an increase because of ageing population and the higher risk of disability in older people will increase in chronic health conditions etc. (WHO, 2011). The largest part of the disabled will be in developing countries because of financial inadequacy and poverty (Eleweke \& Rodda, 2002). It is important to ensure the involvement of the PWD in the planning and design of environment and policies (Charlton, 1998), and it is essential to guarantee their participation in the development of programs targeted at them. The full involvement and integration of PWD can only be achieved through the provision of access and accessibility to knowledge (which will empower them to know what they want) and the environment in which the knowledge is sought (the learning environment - university campuses. Thus, examining the university campus and its responsiveness to the PWD needs is an important part in helping those people to integrate with their communities and in guaranteeing equal access to education and the university campuses for all citizens abled or physically challenged (Riddell, Tinklin, \& Wilson, 2005). There should be no discrimination, segregation or stigmatization. Both developed and developing countries must wake to the rescue of this great number of most marginalized "poorest of the poor". The UN Convention on the Right of Persons with Disabilities (CRPD) brought about a growing awareness to the various Disabled People Organizations (DPOs), operating at national and international levels in different countries.

Nigeria and Malaysia are targeting the attainment of developed nation status by the year 2020. Is accessibility for PWD an issue to be considered in the attainment of that goal? If it is, how far are the preparations in making the environment in general and the university campus in particular barrier free accessible for PWD? This study attempts to answer this question with a goal of identifying accessibility provisions in the policies of Nigeria and Malaysia and compares the environmental response to it. The findings will inform on what to do or what not to do (in either of the countries) towards bringing them to an ideal standard as may be contained in the UN CRPD documents.

\section{LITERATURE REVIEW}

\section{DEFINITIONS OF RELEVANT TERMS}

\section{Disability}

The ancient definition of disability as a loss of functional capability due to illness, injury, accidents or other similar causes (medical model) was redefined, in order to assist the disabled people to gain 
independence, equality and social inclusion by exposing the social oppression associated with disability. In a nutshell disability is a combination of personal tragedy, bio-psycho-social forces and oppressions (Shakespeare \& Watson, 1997).

\section{Disabled students}

Advancement from the studies in the field of disability and sensitivity to the power of human language resulted in an intense debate as to the appropriate terminology to ascribe to the name given to the "handicapped" people. Various scholars prepare the use of the term "disabled people" or "disabled students" (Mji, MacLachlan, Melling-Williams, \& Gcaza, 2009). Critics of this nomenclature, Lewthwaite (2011) pointed out that the emphasis, which is on disability rather than the people, persons or students with disability may be more appropriate. However, Oliver, 1996 in Lewthwaite (2011) rejected this people-first style for no reason but the fact that, here, the disability is defined as part of individual characteristics. Paradoxically, the impairment which qualifies "people with disability" as individuals with inherent incapability is not based on their inability but social and environmental barrier (Goldsmith, 2007). This paper adopted this term "disabled student" to maintain the assumption that the disability becomes compounded on Students with Disability (SWD) if the environment is not supportive but oppressive.

\section{Disabling environment}

The effects of environment on disability are many (Clarke, Ailshire, Nieuwenhuijsen, \& de Kleijinde Vrankrijker, 2011). For over a decade various policies and different regulations were promulgated in countries around the world on the need to make the built environment able to cater for the disabled. In order to achieve this goal various facilities needs to be modified or replaced. Initially architects and planners, following the prevalent notion that disabled people are peculiar and different from "normal" people, created what Goldsmith (2007) called "set of special-for-thedisabled accessibility standards" after conceiving the design for the so-called "normal" people to be added as an afterthought. This is in a way, segregation and disabling and it is more costly. Thus, Universal Design (UD) concept of comes to salvage the situation of the disabled, from disabling environment. Such that the environment can be designed to accommodate both abled and the disabled by assuming that the client/user is a disabled person, the designer will follow a "bottomup-approach" rather than the popular "top down approach" because it is said that "whatever is good for the disabled is good for everybody".

\section{Physical access/accessibility:}

Physical access/ accessibility are to do with the ability to move easily without restrictions either vertically or horizontally and around a facility or feature inside or outside the premises. Physical access is a much discussed subject among disability professionals. Various studies on accessibility provision emphasized the helplessness of disabled in an inaccessible built environment and recommended ways to make the environment disabled friendly (Carr, Frincis, Rixlin,\& Stone, 1992; Metts, 2004). The disability right movement around the world promoted the idea that disabled people should have equal accessibility right to every public facility through architectural modification. 


\section{Physical feature/infrastructural facility}

These are elements of the building design, construction or approach to the building, furniture, fittings appliances and equipment's material finishes or any other entity or dimension of a space situated or positioned temporarily or permanently on the premises.

\section{DISABILITIES AND EDUCATION}

The underrepresentation of disabled students in higher educational participation has been noticed and documented in (Hill, 1992; Riddell et al., 2005), and is more so in developing countries (Mont, 2007) especially Nigeria, where evidences pointed to increase in number of disabled people (Amusat, 2009) decrease in their enrolment into educational pursue (Ozohu-Suleiman, 2012) and inaccessibility of the built environment by disabled people, because of the lack of infrastructure (Hamzat \& Dada, 2005), inadequate budgetary allocations (Ozohu-Suleiman, 2012), lack of policy implementations (Eleweke, 1999). While the international human rights framework has changed lives in some developing and most developed countries, PWD have not reaped the same benefits in Nigeria. PWD in Nigeria are being denied the access to education that would enable them to be independent, therefore, resorted to be dependent on the kindness or charity of others. Despite the international initiative of CRPD (which Nigeria signed in 2007 and ratified since 2010), accessibility to education is far from being achieved for PWD in most developing countries in general, and in Nigeria in particular. This is unfortunate because education is probably "the greatest investment that any nation can embark upon for the development of its economic, political, sociological and human resources" (Hamzat \& Dada, 2005) and is a good measure of how much interest a government has, and importance it attached to the well-being of her citizens.

\section{LAWS AND THE UNITED NATIONS CONVENTION ON THE RIGHTS OF PERSONS WITH DISABILITIES (UN CRPD), 2008}

The CRPD is the first legally binding International treaty that provides a comprehensive portfolio of disability rights and has the potential to create a paradigm shift in the manner to which disability policy and practices were formulated and implemented. The CRPD is based on the existing human rights principles, especially the fundamental rights of non-discrimination (Lang, Kett, Groce, \& Trani, 2011). Globally, PWD have poorer health outcomes (WHO, 2011) and lower education achievements (Filmer, 2008). The United Nation (UN) CRPD came into force in May, 2008 and it is a landmark treaty that reinforced the understanding of disability as human rights and development priority. The implementation of the CRPD is going to be difficult not only because of complex "rights based" but because often times, development practitioners and policy makers do not consider disability issues until they becomes a significant impediments to achieving core objectives or when the disability prevalent rates become high to dictate moral imperative to take action (Lang et al., 2011). In the words of Hathaway, the UN CPRD could be a policy document that may not see the light of the day in the countries where it is needed most as many of the past treaties were seen as mere cheap talks or dead letters.

\section{"Because there is almost no international enforcement of most human rights treaties, some scholars have treated these treaties as dead letters - as, mere cheap talk with virtually no impact on state practice" (Lang et al., 2011).}

Accessibility is important in daily life when dealing with external and internal environment (Soltani, Sham, Awang, \& Yaman, 2012). Accessibility to the built environment is one of the significant barriers to the full participation of PWD in the society (Clarke et al., 2011). Miles (2009) 
asserted that PWD have not been treated as equals to "non-disabled". Malaysia in the attempt to ensure that PWD have equal rights and opportunities as others made changes to her laws. Between 1990 and 2003, standard Codes of Practice were introduced and revised to ensure accessibility and mobility of PWD. In 2008 PWD Act was introduced following Malaysian endorsement of the UN CRPD. The Act harmonized with CRPD, promotes rights of accesses for PWD to public facilities, housing, transport and ICT as well as to education and employment, cultural life and sport (Hussein $\&$ Yaacob, 2012)

\section{Nigerian and Malaysian commitment to UN CRPD agreement}

Nigeria is among the first nations/countries of the world to ascent to the UN CRPD in 2007 and ratified same in 2010. Prior to this, Nigeria promulgated a decree christened: Nigeria with Disability Decree 1993 stating unflinching right and privileges of PWD in Nigeria which include health (Section 4), education (Section 5), vocation and employment (Section 6), accessibility (Section 8) and transportation (Section 9) among others. Section 5 sub-sections 1 decreed free education for the disabled in Nigeria at all levels while Section 5 sub-section 2.3 .2 mandated government organisations and authorities to ensure structural adaptability of all educational institutions to the needs of the disabled. Section 8 reinforced accessibility of PWD to public institutions and facilities. Despite this robust provisions of the Disability Decree of 1993, the provisions of Section 17 of Nigeria 1999 constitution and Nigeria's endorsement of the UN CRPD, Nigeria is still one of the countries with least attention to the problem of PWD. Nigerian disable are still poor, marginalized, stigmatized and excluded (Amusat, 2009; Lang \& Upah, 2008). A review of the disability issues in Nigeria identified many factors why the disability agenda continue to suffer to include absence of discrimination law/provisions, lack of social protection, poor understanding of disability issues by public among others (Amusat, 2009). In recognition of the need for the protection of PWD in Nigeria, various reports recommended collection of reliable data, and advocate for the passage of disability bill into law (Amusat, 2009; Lang \& Upah, 2008). A non-governmental human right advocacy group, based in the UK wrote a letter (signed by the executive director Dimitrina Petrova in 2011 to the president of Nigeria requesting urgent assent to the bill for the full integration of PWD in Nigeria (Petrova, 2011). Yet, the bill has not been passed to law till date. Malaysian commitment towards the implementation of UN CRPD was comprehensive and documented with research evidences (Dort, Coyle, Wilson, \& Ibrahim, 2013).

\section{THE POLICY AND PLANNING PROVISION FOR PWD}

Policy which takes the needs of the majority (is the one that) assumes that people faces different form of barrier in their daily life activities. It therefore becomes important that the built environment in general and educational institutions in particular be made accessible and barrier-free through design. This will make the environment easy for most people to use and with minimal assistance. New world-wide and local policies, legislations and laws have focuses on the paradigm of inclusivity and inclusive schooling as proposed by the UNESCO "policy of inclusive education". The UNESCO policies on education which originated from the Salamanca Conference of 1994 UNESCO 1994 is being adopted by many countries to reduce the discriminatory attitudes towards PWD (Munyi, 2012). The framework of UNESCO 1994 action put emphasis on "education for all" as a basic human right regardless of ability/disability (Ainscow, 1995). The United Nation (UN) Standard rules of equalization of opportunities for PWD enacted in 1993 promulgated that individual nation should adopt the approach of integration on equal basis both in the primary, secondary and tertiary educational levels between PWD and those without. This is a definite backing for inclusive education which must also be replicated in the tertiary level of education - the university. 


\section{The Nigerian experience}

Despite of the social rights guaranteed under the Nigerian 1993 Disability Right, most disabled lived up begging on the city streets (see Figure $1 \mathrm{a} \& 1 \mathrm{~b}$ below). Two noteworthy bills for PWD were presented at the National Assembly in the year 2000 viz.; (1) A bill for an Act to provide special facilities for the use of PWD in the public buildings and (2) A bill for an act to establish a National Commission for the PWD which was vested with the responsibility for PWD education and social development as well as other associated needs of the PWD. Yet, nothing significant came out of these bills; a wide ranging gap between policy statements and policy implementation is clear, vivid and consistent as well as measurable in Nigeria (Eleweke, 1999). Figures 1a and 1b below reflect the 'take care of yourself' approach of the impoverished PWD in Nigeria
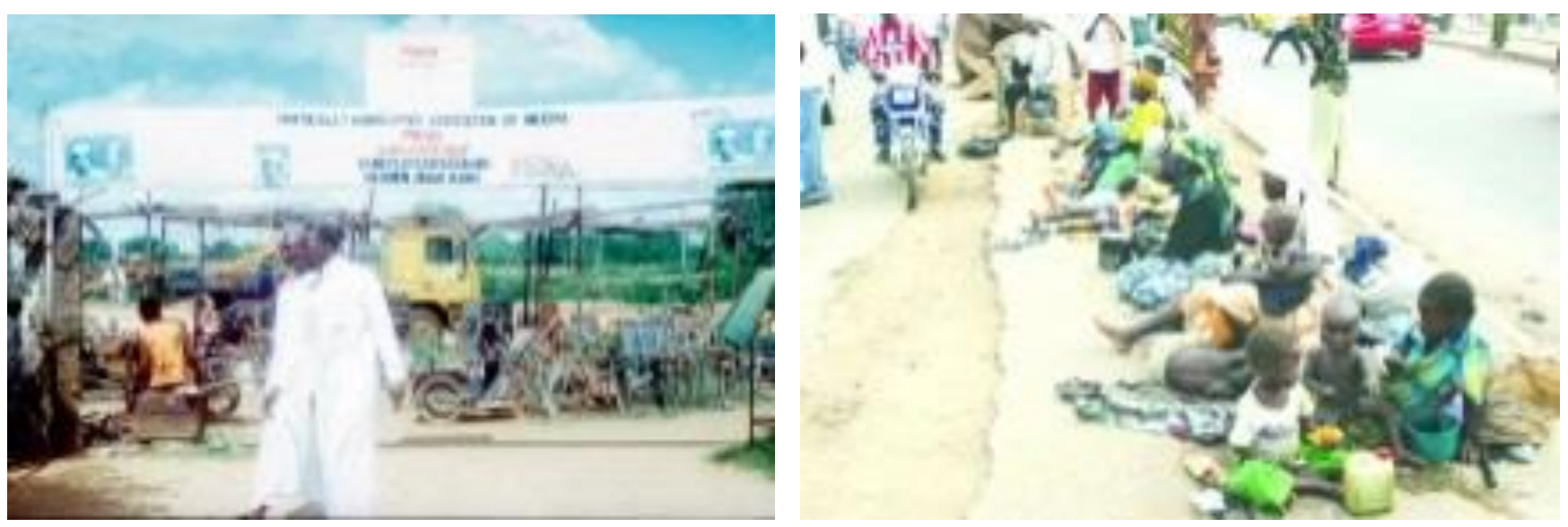

Figure 1a \& 1b: 'Take care of yourself’ approach

\section{The Malaysian experience}

The Malaysian PWD Act 2008 (Act 658) made holistic provisions for the PWD in Malaysia. The Act is a comprehensive one made as an offshoot of the UN CRPD which Malaysia endorsed and ratified in 2007 and 2010 respectively. In the effort to achieving developed nation status by year 2020, the government recognised the need to improve the quality of life of the citizens (abled and disabled). While acknowledging and accepting the social concept of disability, the 2008 PWD Malaysian Act, sees disability (more) as a result of environmental and social barrier and not the physical impairment of the victims. Therefore, disability is much more of environmental barrier and hindrances that affect full participation, interaction and effectiveness of PWD (PWD Act 658 Malaysia, 2008:7 (Hussein \& Yaacob, 2012). The Act also interprets and adopts the concept of universal design (UD) in an effort to meet up with international standards. The International Islamic University in Malaysia has incorporated "barrier free architecture" in the architecture curriculum Ayres I, Braithwaite J. (Shakespeare \& Officer, 2011). Since UD is accepted to be more embracing of all categories of people in the society, a "Barrier-free Universal Design Concept is a better solution. Like Nigeria, Malaysia have policies that deal with welfare of the PWD prior to the Act 658, Malaysia with disability Act 2008 such as the Welfare Policy (1990), National Social Policy (2003), National Policy for PWD (2007) and National Plan of Action for PWD (2007-2012). The key provisions are highlighted (Table 1). 
Table 1: Disability Laws in Nigeria and Malaysia

\begin{tabular}{|c|c|c|}
\hline $\begin{array}{l}\text { Country/ } \\
\text { Disability Law }\end{array}$ & Section & Key Emphasis \\
\hline \multirow{16}{*}{$\begin{array}{l}\text { Nigeria/ Nigerians } \\
\text { with Disability } \\
\text { Decree } 1993\end{array}$} & Section 1 & Standards for enforcement \\
\hline & Section 2 & Equal treatment \\
\hline & Section 3 & Meaning of disability in national context \\
\hline & Section 4 & Equal access to health services etc \\
\hline & \multirow[t]{5}{*}{ Section 5} & 5.1- free education at all levels \\
\hline & & 5.3.2-strucural adaptation of all educational institutions \\
\hline & & 5.4.2.1- provision of special needs of the disabled \\
\hline & & $\begin{array}{l}\text { 5.4.2.5 improve university education facilities to ensure } \\
\text { maximum benefit for the disabled }\end{array}$ \\
\hline & & $\begin{array}{l}\text { "Government shall ensure that no less than } 10 \% \text { of all } \\
\text { educational expenditures are committed to the educational } \\
\text { needs of the disabled at all levels" }\end{array}$ \\
\hline & Section 6 & Without discrimination \\
\hline & Section 7 & Access and accessibility \\
\hline & \multirow[t]{2}{*}{ Section 8} & $\begin{array}{l}\text { 8.1- "accessibility to public institutions and facilities are } \\
\text { hereby guaranteed to the disabled" }\end{array}$ \\
\hline & & $\begin{array}{l}\text { 8.2- government shall provide (a) adequate mobility within its } \\
\text { facilities (b) suitable exits for the disabled }\end{array}$ \\
\hline & Section 9 & \multirow{3}{*}{$\begin{array}{l}\text { Access and accessibility to the facilities, services and } \\
\text { infrastructures }\end{array}$} \\
\hline & Section 10 & \\
\hline & Section 11 & \\
\hline \multirow{10}{*}{$\begin{array}{lr}\text { Malaysia/ } & \\
\text { Malaysian } & \text { PWD } \\
\text { Act } 2008 \quad(\text { Act } \\
685)\end{array}$} & Section:2 - & $\begin{array}{l}\text { Universal design was defined as "design of products, } \\
\text { environment and programs and services to be usable by all } \\
\text { people, to the greatest extent possible, without the need for } \\
\text { adaptation or specialized design and shall include assistive } \\
\text { devices for a particular groups of PWD where this is needed" }\end{array}$ \\
\hline & Part- IV & Improving the Quality Of Life (QOL) for PWD \\
\hline & Section: 26 & $\begin{array}{l}26.1- \\
\text { PWD shall have the right to access to use of; public facilities, } \\
\text { amenities, services and buildings (open or provided to public) } \\
\text { on equal basis with Persons without disabilities. }\end{array}$ \\
\hline & & $\begin{array}{l}26.2- \\
\text { "For the purpose of subsection } 1 \text { above, the Government and the } \\
\text { providers of such public facilities, amenities, services and } \\
\text { buildings shall give appropriate consideration and take } \\
\text { necessary measures to ensure that such public facilities, } \\
\text { amenities, services and buildings and the improvement of } \\
\text { equipment's related thereto conform to Universal Design in } \\
\text { order to facilitates their access and use by PWD" }\end{array}$ \\
\hline & Section: 27 & Access to public transport facilities \\
\hline & Section: 28 & Access to education \\
\hline & Section: 29 & Access to employment \\
\hline & Section: 30 & Access to information and communication technology \\
\hline & Section: 31 & Access to cultural life \\
\hline & Section: 32 & Access to, recreation, leisure and sport \\
\hline
\end{tabular}

(Source: Authors' compilation from the respective laws) 


\section{METHODOLOGY}

A case study research approach was adopted for this study. The case study was assessed based on the usage of matrix containing the pre-determined factors with weightage given. Access audit checklist was used to assess the presence of facilities for disabled. Data with respect to number of accessibility elements that are provided in selected buildings of common patronages for all university students and pictures were taken to analyse the adequacy and functionality of these infrastructures where they are provided. Using case studies and literature review, the first part of this comparative research accesses and evaluates the presence of environmental barriers as they affect way-findings by PWD and in particular persons with mobility limitation (PWML). Ahmadu Bello University (ABU Zaria) was selected from Nigeria and the result compared as it agrees or disagree with the "Nigerian with Disability Decree 1993". University of Malaya (UM) was selected from Malaysia and result compare with Disability Act of 2008. The study required to examine the existing buildings against predetermined criteria designed to measure the usability or otherwise of the buildings by the PWD. The usability in this research encompasses getting in and getting around to getting out. In other words, it determines how much of the facilities can be used independently by PWD and also to reveal the difficulty PWD may encountered while using the buildings. Ahmadu Bello University (ABU), Zaria which was established in 1961 has increased in size and scopes so rapidly that now "it is the largest and the most extensive of all universities in sub-Saharan Africa" with area covering a land of about 7,000 hectares and encompassing two campuses. For the purpose of this study only the main campus will be considered. While the selection of University of Malaya was informed by the fact that it is the oldest and top university in Malaysia. The case study was assessed based on the criteria of adequacy and usability or otherwise of building entrance ramp for wheelchair users, automatic doors for the visually challenged, elevators in storey buildings for the walking impaired, kerbings, modified washrooms for the physically challenged and seating for the disabled. These predetermine accessibility criteria were analysed in a matrix form- as in Table 2 below. Ten (10) focused structure and area of accessibility consideration from each university are the senate/chancellery building, library, hospital, lecture theatre, lecture room, sport centre, student hostel, recreational centre and banks. The process employed to make judgement about the response of the individual character of the built environment to relevant policy objective as summarized in a matrix study-site observation accessibility checklist.

\section{RESULT AND ANALYSIS}

This research was conducted on facilities/buildings that students, disabled or not used more often. Out of such spaces the study selected ten (10) in comprising of; Senate Buildings/ Central Administration, Library, University Health centres/Hospital, Lecture Theatres and Rooms, Sports and Recreation facilities, Student Hostel and banks. The accessibility elements available include ramps to buildings, automatic doors, and elevators in multi-storey buildings, kerbs, washrooms, seating and designated parking. The data was ascribed a rank of between $0,1,2$ or 3 . The buildings/facilities that have $100 \%$ accessibility provisions were ranked 3 , those with $50 \%$ and above ranked 2, those with less than $50 \%$ ranked 1 while those with no provisions ranking 0 . The rankings were summed up for deductions. Table 2 and Figure 2 show the distribution of the facilities in the case studies. 
Table 2: Data presentation for accessibility at ABU and UM

\begin{tabular}{|c|c|c|c|c|c|c|c|c|c|c|c|c|c|c|c|c|c|c|c|c|c|c|c|c|}
\hline \multicolumn{25}{|c|}{ UNIVERSITIES } \\
\hline & \multicolumn{12}{|c|}{ Ahmadu Bello University Zaria (ABU) } & & \multicolumn{11}{|c|}{ University of Malaya (UM) } \\
\hline Facilities/ Buildings & 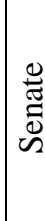 & 矛 & 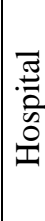 & 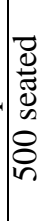 & 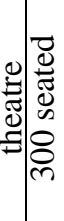 & $\begin{array}{l}0 \\
\stackrel{0}{\Xi} \\
=\end{array}$ & 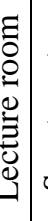 & 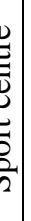 & 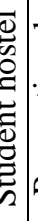 & 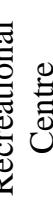 & 铓 & $\frac{\pi}{9}$ & $=$ & 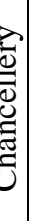 & $\begin{array}{l}\overrightarrow{0} \\
\overrightarrow{3} \\
\vec{a}\end{array}$ & 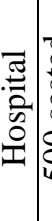 & : & 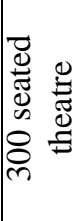 & 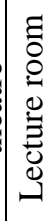 & 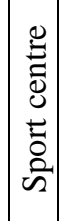 & 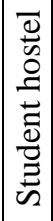 & 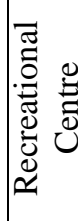 & 券 & 趈 \\
\hline Total & 3 & 3 & 3 & 3 & & 3 & 3 & 3 & 3 & 3 & 3 & 30 & & 3 & 3 & 3 & 3 & 3 & 3 & 3 & 3 & 3 & 3 & 30 \\
\hline $\begin{array}{l}\text { Building Entrance } \\
\text { Ramps }\end{array}$ & 1 & 0 & 2 & 1 & & 2 & 0 & 1 & 0 & 1 & 0 & 8 & & 2 & 2 & 2 & 2 & 2 & 2 & 2 & 1 & 1 & 1 & 17 \\
\hline Automatic doors & 0 & 0 & 0 & $\mathrm{c}$ & & 0 & 0 & o & 0 & 0 & 0 & 0 & & 2 & 2 & 2 & 0 & 0 & 0 & 0 & 0 & 0 & 2 & 8 \\
\hline $\begin{array}{l}\text { Elevators: storey } \\
\text { building }\end{array}$ & 1 & 0 & 0 & c & & 0 & 0 & o & 0 & 0 & 0 & 1 & & 3 & 3 & 3 & 0 & 0 & 2 & 2 & 2 & 0 & 0 & 15 \\
\hline Kerbings & 2 & 1 & 2 & 1 & & 2 & 1 & 1 & 0 & 1 & 0 & 11 & & 2 & 2 & 2 & 2 & 2 & 2 & 1 & 1 & 2 & 0 & 17 \\
\hline Modified wash rooms & 0 & 0 & \begin{tabular}{|llllll} 
& 1
\end{tabular} & c & & 0 & 0 & o & 0 & 0 & 1 & 1 & & 2 & 1 & 1 & 0 & 0 & 0 & 0 & 0 & 0 & 0 & 6 \\
\hline Seating for the Disabled & 0 & 0 & 1 & ( & & 0 & 0 & & 0 & 0 & 0 & 1 & & 1 & 3 & 3 & 2 & 2 & 2 & 1 & 0 & 1 & 0 & 14 \\
\hline
\end{tabular}

(Source: Authors' survey)

The staked column chart

Legend

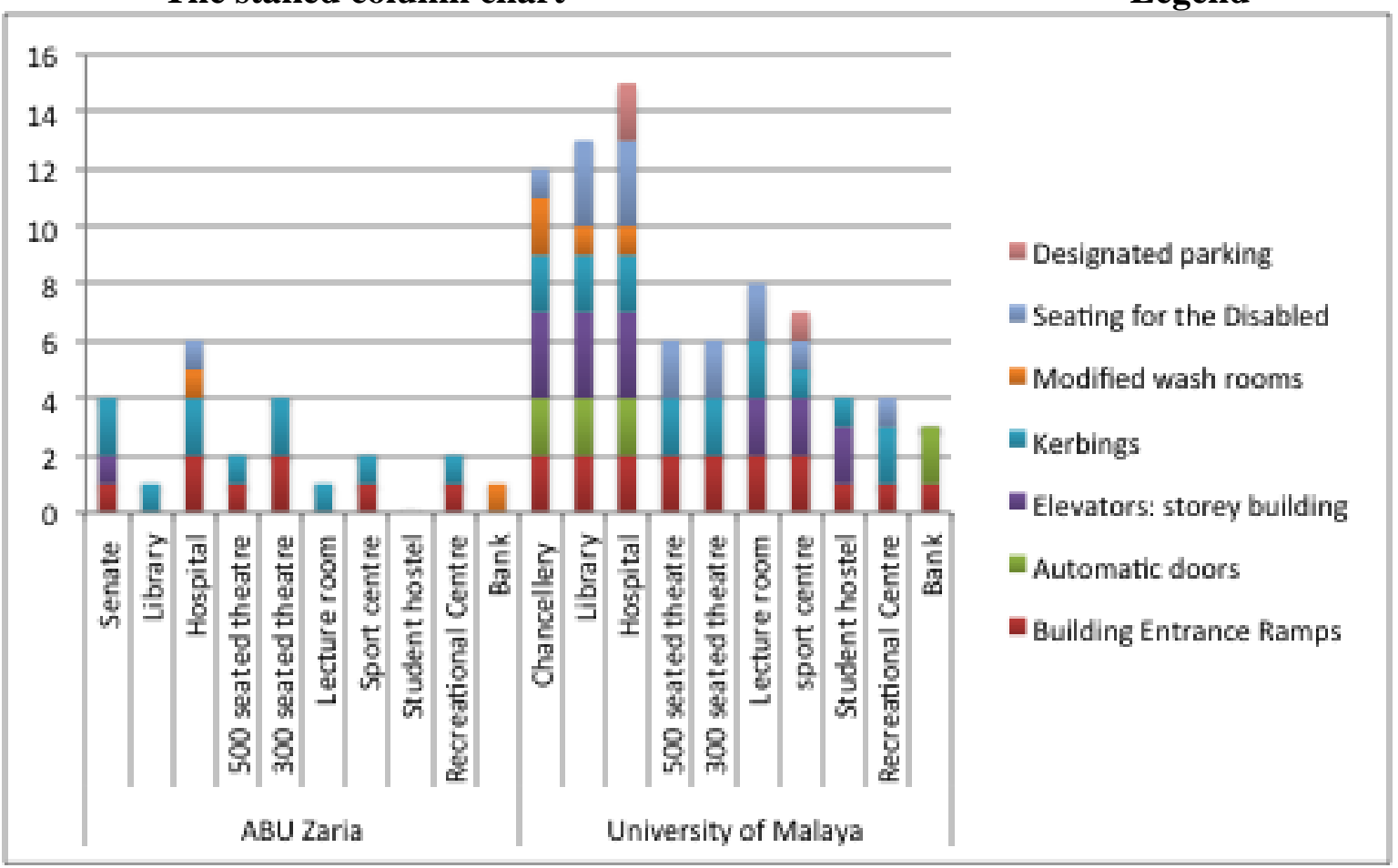

Figure 2: Accessibility Facilities' Distribution in ABU and UM 
Table 3: Summary of finding

\begin{tabular}{|c|c|c|c|c|}
\hline $\begin{array}{l}\text { Building/ } \\
\text { facilities }\end{array}$ & $\begin{array}{l}\text { ABU } \\
\text { Zaria }\end{array}$ & Remarks & UM & Remarks \\
\hline Total & 30 & 100.0 & 30 & 100.0 \\
\hline $\begin{array}{l}\text { Building } \\
\text { Entrance } \\
\text { Ramps }\end{array}$ & 8 & $\begin{array}{l}\text { 26.7\% provisions of ramps in ABU buildings } \\
\text { are greatly inadequate. Only the hospital was } \\
\text { ascribed a score of } 2 \text { which indicated that } \\
50 \% \text { or more of the entrance of the hospital } \\
\text { have ramp, however, the ramps were not } \\
\text { originally design to create access for the } \\
\text { PWD but for the hospital stretchers and } \\
\text { wheelchairs for patients. This means that } \\
\text { PWD are not in the consideration in the } \\
\text { design and construction of the campus. }\end{array}$ & 17 & $\begin{array}{l}\text { All facilities recorded average score } \\
(56.7 \%) \text { aside from student hostels, } \\
\text { recreational centres and bank with a } \\
\text { below average provision of entrance } \\
\text { ramp which means the emphasis was } \\
\text { on educational needs, health and } \\
\text { employability rather than welfare and } \\
\text { social interaction with PWD. As such } \\
\text { more needs to be done in the student } \\
\text { hostels, banks, recreational and sport } \\
\text { centres }\end{array}$ \\
\hline $\begin{array}{l}\text { Automatic } \\
\text { doors }\end{array}$ & 0 & $\begin{array}{l}\text { No Automatic door exists in all the important } \\
\text { facilities. This is contrary to expectation for } \\
\text { the largest university in sub-Saharan Africa }\end{array}$ & 8 & $\begin{array}{l}\text { Chancellery, hospital bank and } \\
\text { library meet up with the requirement } \\
\text { for the PWD in this respect but other } \\
\text { buildings need an upgrading. }\end{array}$ \\
\hline $\begin{array}{l}\text { Elevators: } \\
\text { storey } \\
\text { building }\end{array}$ & 1 & $\begin{array}{l}\text { The whole school has only three numbers of } \\
\text { lifts which is } 3.3 \% \text { out of which one is } \\
\text { dedicated to the management at the } 7^{\text {th }} \text { floor, } \\
\text { the Vice Chancellor and the conference hall } \\
\text { at the } 9^{\text {th }} \text { floor. This is grossly inadequate for } \\
\text { a building that houses hundreds if not } \\
\text { thousands of people. } \\
\text { All other storey buildings do not have lift }\end{array}$ & 15 & $\begin{array}{l}\text { Some building like lecture rooms or } \\
\text { theatres, banks and recreational } \\
\text { centres are bungalows and does not } \\
\text { require lift/elevator. Therefore it can } \\
\text { be said that there is } 100 \% \text { provision } \\
\text { for lift in UM }\end{array}$ \\
\hline Kerbings & 11 & $\begin{array}{l}\text { The score of } 11(36.7 \%) \text { with respect to } \\
\text { curving in ABU averaged to a kerbs for each } \\
\text { observed building with hospitals again } \\
\text { having the highest number of curving for the } \\
\text { convenience of hospital services; rather than } \\
\text { PWD usage. }\end{array}$ & 17 & $\begin{array}{l}56.7 \% \text { for turning radius is not an } \\
\text { acceptable level for UM. While } \\
\text { provisions of ramps are made with } \\
\text { inadequate turning or too steep rising, } \\
\text { the ramps become not useful. }\end{array}$ \\
\hline $\begin{array}{l}\text { Modified } \\
\text { wash rooms }\end{array}$ & 1 & $\begin{array}{l}\text { No modified washrooms exist for the use of } \\
\text { PWD, } 1 \text { score recorded in the hospital is for } \\
\text { medical reason rather than PWD Needs. This } \\
\text { amount to a poor score of } 3.3 \%\end{array}$ & 6 & $\begin{array}{l}20.0 \% \text { for modified washroom is } \\
\text { inadequate in UM. The study found } \\
\text { that the washrooms are not } \\
\text { convenient for the PWD }\end{array}$ \\
\hline $\begin{array}{l}\text { Seating for } \\
\text { the Disabled }\end{array}$ & 1 & $\begin{array}{l}\text { Only } 1 \text { score was recorded for seating for the } \\
\text { disabled, that too is from the hospital. This } \\
\text { indicates that PWD are regarded as "only } \\
\text { medically needy". So the inadequate } \\
\text { provisions for them are always cited at the } \\
\text { hospital. }\end{array}$ & 14 & $\begin{array}{l}\text { The outside relaxation seats that } \\
\text { could foster inclusion of PWD is not } \\
\text { accessible to wheel chair users, } \\
\text { though there is } 46.7 \% \text { provision }\end{array}$ \\
\hline $\begin{array}{l}\text { Designated } \\
\text { parking }\end{array}$ & 0 & $\begin{array}{l}\text { There are no designated parking for PWD in } \\
\text { ABU }\end{array}$ & 3 & $\begin{array}{l}\text { The } 10.0 \% \text { recorded for the } \\
\text { designated parking space is seen at } \\
\text { the hospital where the park is } \\
\text { labelled. The faculty of economics } \\
\text { and the recreation centre has similar } \\
\text { provision but unlabelled }\end{array}$ \\
\hline
\end{tabular}




\section{DISCUSSION AND IMPLICATION OF RESEARCH}

The result indicates that Malaysian universities as represented in this study by University of Malaya has better provision for the PWD than Nigeria. This could be attributed to commitment of Malaysia government and the educational administrator in the pursuance of the right of PWD. However, the Nigeria situation should be attributed to something other than poverty level (Nigeria being one of the largest oil exporters in the world). However the study further reveals that though the facilities are seen provided in Malaysia, some are inadequate, while others are not meeting the expectation of the targeted groups of PWD. For instance where a turning radius is inadequate it will constitute a difficulty for a wheelchair to manoeuver. Mere provision of what is required is a step; functionality is another while satisfactory use is the target.

Again, wash rooms are provided but difficult for disabled to use (in most cases the doors are opening to the inside. The spaces or details such as door width measures too small or narrow and become inconvenient for PWD (to manoeuvre). Designated car parks for the wheelchair users were sighted at the hospital UMMC (Figure 4), Faculty of Built Environment and Department of Economics, more needs to be provided elsewhere. In essence UM has not reached the acceptable standard and provision for PWD. The PWD in UM are adapting to what is provided as the provisions were not adequate to cater for SWD needs. Table 3 presents the findings of the study. Therefore the UD concept of bottom-up approach should be adopted "as anything useable for the disabled is useable for anyone else" rather than adaptation method.

\section{FINDINGS ON NIGERIAN UNIVERSITY IN THE LIGHT OF GOVERNMENT POLICIES CONCERNING PWD}

Nigeria promulgated in 1977, a policy with a complete chapter to provide for the educational need of PWD. The policy was revised in 1981 in which article 55 provided additional promises for PWD. Article 56 stated (among others) that the government will provide necessary facilities for the integration of PWD in regular educational institutions. In 1993, the Nigerian with Disability Decree was promulgated to further address the needs of the PWD with more focus on educational rights and accessibility in all senses to educational facilities. Following the Nigeria ratification of the UN convention, various policies were developed on special education needs. Such policies include; education as contained in the Millennium Development Goal (MDG), Universal Basic Education (UBE) and Education for All (EFA) by the year 2015. In order to meet with these policy targets, educational institutions must be barrier-free to ensure easy accessibility for all. Despite the provisions of fully inclusive and integrated education for all, a look around reveals that the number of PWD on university education is of negligible percentage of the student's enrolment. Aromolaran (2005) stated that only 50,000 "handicapped children" are in special school receiving education which is $0.03 \%$ of the population of the disabled in Nigeria. Out of this how many will get to University level? Previous studies has shown that majority of PWD do not go beyond secondary school level (Hill, 1992). Although the reason for their under representation in university system has not been established, availability of supportive services and accessible infrastructures including buildings are factors of importance. Removal of architectural barriers could increase accessibility in university campus for the PWD, and eliminates what Goldsmith (2007) called architectural disability.

Freedom from all forms of discrimination against any person was assured in Section 42 of the 1999 Nigerian constitution; thus it includes freedom for PWD as well. Before 1999, the Nigerian with Disability Decree of 1993 made many provisions for the protection of human rights of PWD (Table 
1). Section 2 guaranteed equal treatments. However, this study shows unequal treatment accessibility wise. Section 3 defined and provides laws on human rights and privileges of PWD. While Section 4 stressed equal access to health services (which universities hospitals should provide); the result of this study indicates poor score of $29 \%$ accessible facilities in the school hospital. Nonetheless, hospital is found to be the most accessible structure in ABU, even though, it is not close to meeting the policy provision as contained in section 5 and section 8 of the national policy abridged in (table 1). But the overall accessibility scores in percentage are $7 \%, 0 \%, 3.3 \%$, $37 \%, 3.3 \%, 3.3 \%$ and $0 \%$ for building entrance ramp, automatic doors, elevators in storey buildings, kerbings, modified washrooms, seating for PWD and designated parking space respectively.

Thus, Nigerian campus is not the (most) conducive place for a PWD to be. Section 6 of the disability policy stresses the right of PWD (on paper) to enjoy employment without discrimination; all the same, senate or chancellery building has a poor score of $19 \%$, how can a PWD manage even if ever employed, to move into and within the building, when the built environment is glaringly disabling and unfriendly? Section 14 recognized the need for the establishment of National commission for PWD, but nothing concrete is yet to be seen to match the provision with action. To date, no record of the National Commission for PWD is found, contrary to Section 9 of the Decree, transport (which is another form of accessibility provision) is neither free nor adequate for the disabled contrary to volumes of printed documents. National news and official broadcasts do not provide sign language for interpretation in accordance with Section 19. It is unimaginable that the country had no commitment to the physical need of her disabled population, as there are no adequate provisions to back up the documents. Majority of public universities in Nigeria look up to ABU as a role model university. It however lacks the facilities to support integrated and inclusive education for the disabled, which has been declared a right for all by the UN CRPD. A building by laws that will integrate PWD into urban and regional designs is therefore inevitable specifically university campuses. More so, collections of data on PWD is important in order to identify and develop strategies for the improvement of their "Quality of life (QOL)", without which the government may not be able to plan or know the amount of resources to allocate for an organized service delivery.

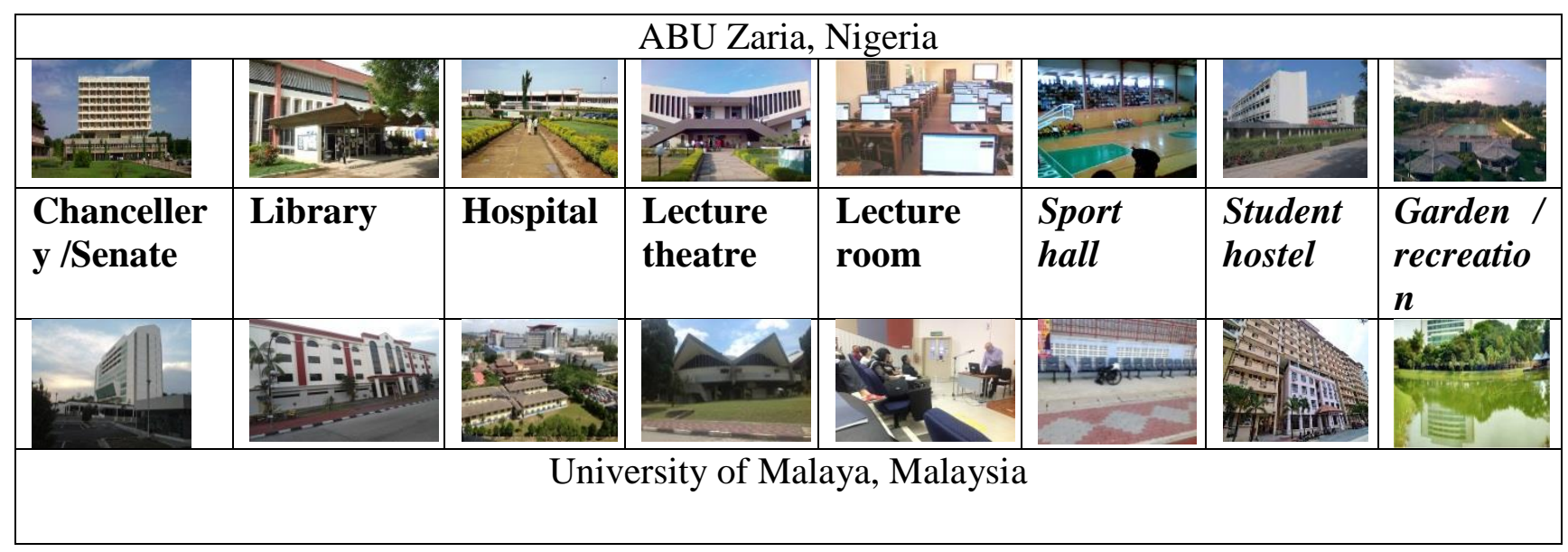

Figure 4: ABU Zaria, Nigeria and University of Malaya, Malaysia

(Source: Authors and compilation from Ahmadu Bello University website, www.informationng.com,nairaland.com and the UM website) 


\section{FINDINGS ON MALAYSIAN UNIVERSITY IN THE LIGHT OF GOVERNMENT POLICIES CONCERNING PWD}

Following the endorsement of the Asia- Pacific Region's Proclamation on the Full Participation and Equality of PWD in 1994, Malaysian became more active in the provision of accessibility infrastructure in the built environment (Hussein \& Yaacob, 2012). In addition to education as a right for PWD, the United Nation (UN) CRPD declared the rights of PWD to include accessibility to public buildings; such as campus buildings, transportation, education etc. UN CRPD as a universal treaty was signed and ratified by several nations Malaysia included. By implication, country that sign and ratify the convention, has agreed to abide by the policy provisions. Malaysian enacted Persons with Disability Act (658) of 2008 prior to ratification of the UN CRPD. The Act provided for the inclusion of PWD in education system with additional responsibility for educational provision to make reasonable and suitable accommodation for PWD including recreational, leisure and sporting activities (Hussein \& Yaacob, 2012).

After the preliminary section in Section 2 (of Malaysia with Disability Act 2008), proclamation was made, defining the meaning of Universal design (UD) in national context. UD was defined as a "design of products, environment and programs and services to be usable by all people, to the greatest extent possible, without the need for adaptation or specialized design, and it shall include assistive devices for a particular groups of PWD, where this is needed". This is the first positive step that needs to be implemented. Example of UD can be seen in the Figure 6 below.

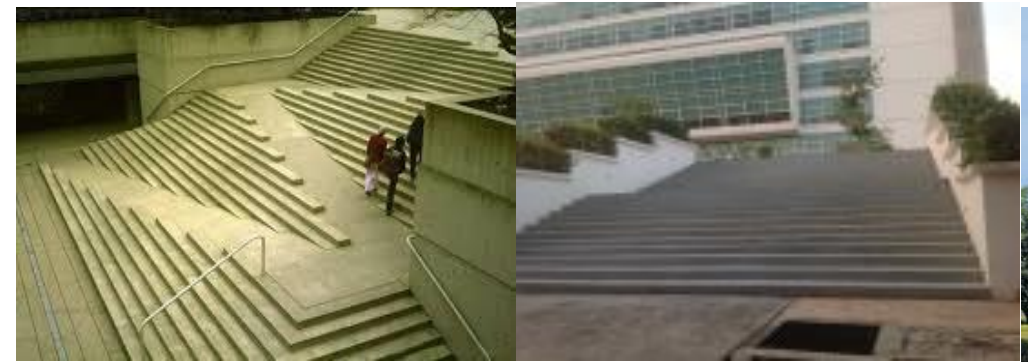

(a) UD

(b) UM

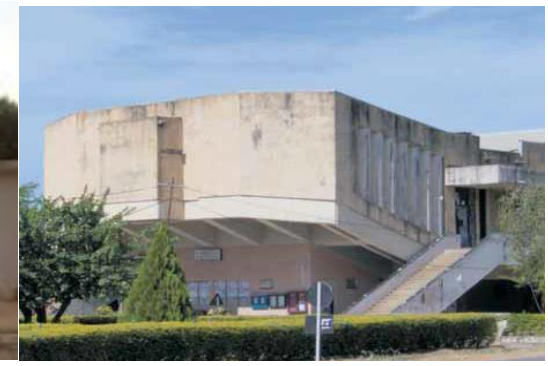

(c) $\mathrm{ABU}$

Figure 6: (a) the facility is designed in UD concept with bottom up approach thereby eliminating the extra modification costs.

(b) It was designed with separated side ramps, rendering it more costly and segregating.

(c) Has no provision for ramps

(Source: universaldesign.org, authors and ABU Zaria website respectively)

In Section IV, Improving the Quality Of Life (QOL) for PWD is assured, and the responsibility was stated in clear terms in section 26.2 that:

"...the Government and the providers of such public facilities, amenities, services and buildings shall give appropriate consideration and take necessary measures to ensure that such public facilities, amenities, services and buildings and the improvement of equipment's related thereto conform to Universal Design in order to facilitates their access and use by $P W D^{\prime \prime}$

Access to public transport facilities was guaranteed in section 27 and it is positively free for all students in UM without segregation. Section 28, 29 and 32 are for equality in access to education, employment and recreation, leisure and sport. Expert's clear voices are sounding a warning note, on the need for inter-disciplinary collaboration in order to have a barrier-free built environment in all Malaysian universities e.g. (Hussein, 2005). To achieve this goal, more is needed, to be put in place as indicated by this study. 
Nigeria is still struggling with formulation of strategy for the implementation and evolving building accessibility guidelines, Malaysia on the other hand, is embarking on adaptation of facilities to make them suitable for the use by PWD. Even though more is needed to achieve the satisfactory level of her disabled citizen most specifically the people on wheelchairs, the expectation of the target users of facilities is the key to adequate provision. It is hoped that the PWD will be involved in design and provision of accessibility infrastructures. The integrated facilities in Malaysia are not $100 \%$ in place, therefore it is required to achieve the goal to improve QOL, UD and SD as contain in Malaysia with Disability Act 2008 (Part- IV, Section: 2 \& 26.2) (refer Table 1).

\section{CONCLUSION}

In conclusion both countries are yet to achieve the target set by their respective disability laws and in effect Nigeria has not achieved anything close to the expectation of the UN-CRPD. An adoption and implementation of Universal Design (UD) policy will help in total integration of PWD with the society. Whatever is good for the disable is good for anyone else. To this end, the study recommends as follow:

i. The integration and inclusive approach should be adopted in providing for PWD at all times.

ii. Social sustainability should be given equal treatment with economic and environmental.

iii. Universal Design (UD) concept should be adopted through the provision of friendly built environment for all. The slogan "anything good for the disabled is good for everyone" should be adapted in the provision of facilities and infrastructures.

iv. The bottom-up approach will allow the PWD contribute to policy making with respect to their care rather than the top down approach.

v. The expectation of the PWD with respect to facilities provision should be established and providers strive to meet up.

vi. There is a need to analyse the functionality through physical measurement and comparison with design standards (using a control group). A survey of the expectation and perception of facilities of the PWD will give empirical evidence of the functionality.

In conclusion, this paper has achieved its objective in relation to the subject matter that is identification of relevant buildings and accessibility provisions in them, using Audit checklist, comparison between the adequacies or otherwise of the facilities against the National policy provisions.

\section{REFERENCES}

Ainscow, M. (1995). Education for all: Making it happen. Support for learning, 10(4), 147-155.

Amusat, N. (2009). Disability care in Nigeria: The need for professional advocacy. African Journal of Physiotherapy and Rehabilitation Sciences, 1(1), 30-36.

Aromolaran, E. (2005). Training special educators for low vision children in Nigerian regular schools. Paper presented at the International Congress Series.

Bromley, R. D., Matthews, D. L., \& Thomas, C. J. (2007). City centre accessibility for wheelchair users: The consumer perspective and the planning implications. Cities, 24(3), 229-241.

Carr, S., Frincis, M., Rixlin, L.G. \& Stone, A.M. (1992) Environment and behaviour series public space. The press syndicate the university of cambridge, New York. 
Charlton, J. I. (1998). Nothing about us without us: Disability oppression and empowerment. London, England: Univ of California Press.

Clarke, P. J., Ailshire, J. A., Nieuwenhuijsen, E. R., \& de Kleijn-de Vrankrijker, M. W. (2011). Participation among adults with disability: The role of the urban environment. Social Science \& Medicine, 72(10), 1674-1684.

Dort, S. V., Coyle, J., Wilson, L., \& Ibrahim, H. M. (2013). Implementing the world report on disability in Malaysia: A student-led service to promote knowledge and innovation. International Journal of Speech-language Pathology, 15(1), 90-95.

Eleweke, C. J. (1999). The need for mandatory legislations to enhance services to people with disabilities in Nigeria. Disability \& Society, 14(2), 227-237.

Eleweke, C. J., \& Rodda, M. (2002). The challenge of enhancing inclusive education in developing countries. International Journal of Inclusive Education, 6(2), 113-126.

Filmer, D. (2008). Disability, poverty, and schooling in developing countries: Results from 14 household surveys. The World Bank Economic Review, 22(1), 141-163.

Goldsmith, S. (2007). Universal design: A manual of practical guide for architect. Oxford UK: Routledge.

Hamzat, T., \& Dada, O. (2005). Wheelchair accessibility of public buildings in Ibadan, Nigeria. Asia Pacific Disability Rehabilitation Journal, 16(2), 115-124.

Hill, J. L. (1992). Accessibility: Students with disabilities in universities in Canada. Canadian Journal of Higher Education, 22(1), 48-83.

Holmes-Siedle, J. (1996). Barrier-free design: a manual for building designers and managers. New York, NY 10017, USA: Routledge.

Hussein, H. (2005). Encouraging a barrier-free built environment in a Malaysian university. Journal of Design and Built Environment, 1, 33-40.

Hussein, H., \&Yaacob, N.M. (2012). Development of accessible design in Malaysia. ProcediaSocial and Behavioural Sciences, 68, 121-133.

Lang, R., Kett, M., Groce, N., \& Trani, J.-F. (2011). Implementing the United Nations Convention on the rights of persons with disabilities: Principles, implications, practice and limitations. ALTER-European Journal of Disability Research/Revue Européenne de Recherche sur le Handicap, 5(3), 206-220.

Lang, R., \& Upah, L. (2008). Scoping study: Disability issues in Nigeria. London: DFID.

Lewthwaite, S. (2011). Disability 2.0, student dis/connections: a study of student experiences of disability and social networks on campus in higher education. University of Nottingham, England, PhD Thesis.

Metts, R. (2004). Disability and developoment. Background paper prepared for the Disability and Development Research Agenda Meeting, World Bank Headquarters, Washinton D.C. 16 November 2004.

Miles, S. (2009). Engaging with teachers' knowledge: Promoting inclusion in Zambian schools. Disability \& Society, 24(5), 611-624.

Mji, G., MacLachlan, M., Melling-Williams, N., \& Gcaza, S. (2009). Realising the rights of disabled people in Africa: An introduction to the special issue. Disability \& Rehabilitation, 31(1), 1-6.

Mont, D. (2007). Measuring disability prevalence. World Bank Social Protection Discussion Paper (0706).

Munyi, C. W. (2012). Past and present perceptions towards disability: A historical perspective. Disability Studies Quarterly, 32(2).

Ozohu-Suleiman, Y. (2012). An Assessment of children literacy development in Nigeria in the context of EFA 2015 Policy Targets. Africa Education Review, 9(3), 485-500.

Petrova, D. (2011) His Excellency: The president of Nigeria (urgent assent to the bill for the full integration of PWD in Nigeria) 
Riddell, S., Tinklin, T., \& Wilson, A. (2005). Disabled students in higher education: perspectives on widening access and changing policy. London, England: Routledge.

Shakespeare, T., \& Officer, A. (2011). World report on disability. Disability and rehabilitation, 33(17-18), 1491.

Shakespeare, T., \& Watson, N. (1997). Defending the social model. Disability \& Society, 12(2), 293-300.

Soltani, S.H.K., Sham, M., Awang, M., \& Yaman, R. (2012). Accessibility for the Disabled in public Transportation Terminal. Procedia-Social and Behavioural Sciences, 35, 89-96.

WHO, W. H. O. (2011). Summary: World report on disability 2011. 